\title{
Mannréttindi í Tyrklandi
}

Að mörgu leyti má halda pví fram að heimur batnandi fari. Tekist hefur að lyfta stórum hluta mannkyns úr sárri fátækt í betra skjól, tækni og vísindi taka enn stórstígum framförum og vopnuðum átökum fer fækkandi.

Samt sem áđur láta tugir púsunda enn lífið á hverju ári í hernaði, til dæmis í borgarastyrjöldum í Sýrlandi, Afganistan og Írak og í átökum í mörgum af ríkjum Afríku.

Pá hefur aukinni efnahagslegri velsæld í heiminum ekki fylgt aukið frelsi eða lýðræði. Pvert á móti átti lýðræði hvað erfiðast uppdráttar á liðnu ári samanborið við síðustu áratugi, að mati Freedom House stofnunarinnar. Í nýrri ársskýrslu samtakanna kemur fram að ástand stjórnmálalegra og borgaralegra réttinda í heiminum versnaði 12. árið í röð, batnaði í 35 ríkjum en hrakaði í rúmlega tvöfalt fleiri ríkjum.

Mörg fyrrnefndra ríkja sem búa við viðvarandi vopnuð átök, eru jafnframt pau ríki par sem ástand mannréttindamála er hvað verst. Рað er hins vegar ekki einungis í stríðshrjáðum ríkjum sem mannréttindi eiga í auknum mæli undir högg að sækja heldur hafa pau látið undan síga í sumum af fjölmennustu ríkjum heims, ríkjum sem búa við stöðugleika í stjórnarfari og uppgang í efnahag. Pannig búa til dæmis íbúar í Kína við stórskert borgaraleg réttindi og parlend stjórnvöld taka árlega af lífi mörg púsund manns. Pá sjást einnig blikur á lofti jafnvel í ríkjum sem hafa til skamms tíma verið leiðandi á sviði mannréttindabaráttu, svo sem Bandaríkjanna.

Við pessar aðstæður sækja alræðisstjórnir og einræðisherrar í sig veðrið og seilast lengra en peir pyrðu ella. Meðal fórnarlamba peirra er fólk sem stjórnvöld telur óæskilegt, svo sem dómarar sem ekki láta að stjórn, fréttafólk sem flytur ópægilegar fréttir, baráttufólk fyrir réttindum minnihlutahópa, læknar sem hlúa að hinum óæskilegu og lögmenn sem sækja rétt peirra. Í nýrri ársskýrslu Front Line Defenders kemur fram að á liðnu ári lét fólk lífið í 27 ríkjum heims fyrir friðsöm mótmæli sín gegn mannréttindabrotum og hefur fjöldinn aukist ár frá ári.

раð ríki par sem staða mannréttinda hefur versnað hvað hraðast á síðustu árum er Tyrkland.
Parlend stjórnvöld hafa á síðustu árum pjarmað jafnt og pétt að helstu borgaralegum réttindum, svo sem tjáningarfrelsi og réttinum til sanngjarnrar málsmeðferðar. Í kjölfar valdaránstilraunar í júlí 2016 jukust pessir tilburðir stórkostlega með fjöldahandtökum og ákærum fyrir oft á tíðum fráleitar sakir. Á annað hundrað púsund einstaklingar hafa verið handteknir eða reknir úr störfum sínum, par af hafa 40.000 verið hnepptar í varðhald en af peim eru hátt í 3000 dómarar, 10.000 hermenn og 15.000 kennarar.

Pessi mannréttindabrot hafa ekki vakið jafn hörð viðbrögð annarra ríkja alpjóðasamfélagsins og búast mátti við. Pannig hefur Evrópusambandið haldið áfram vafasömu samstarfi sínu við tyrknesk yfirvöld um að stöðva för flóttafólks frá Sýrlandi til Evrópu. Tyrknesk stjórnvöld hafa pví gengið á lagið og beina nú spjótum sínum í auknum mæli gegn peim sem pau virðast telja sér stafa ógn af. Hafa handtökur og ákærur pví stöðugt meira beinst gegn blaðafólki og baráttufólki fyrir mannréttindum. Pannig voru bæði framkvæmdastjóri og formaður tyrknesku deildar Amnesty International hneppt í varðhald á liðnu ári og bíða nú bæði dóms fyrir sakir á borð við samsæri gegn ríkinu.

Tyrknesk stjórnvöld hafa nú gengið enn lengra og dæmt hóp blaðamanna í lífstíðarfangelsi fyrir umfjöllun sína um stjórnmálaástandið í landinu. Pá voru 11 meðlimir tyrkneska læknafélagins hnepptir í varðhald og ákærðir fyrir landráð, að pví er virðist fyrir pað eitt að gagnrýna hernaðarbrölt stjórnvalda. Bæði mannréttindasamtök og ýmis samtök lækna hafa mótmælt pessu kröftuglega. Virðist sem pað kunni að hafa átt pátt í pví að læknarnir hafa nú verið leystir úr varðhaldi.

Prátt fyrir að alpjóðasamfélagið hafi hingað til ekki tekið nægilega hart á einræðistilburðum tyrkneskra stjórnvalda eru pau samt sem áður viðkvæm fyrir almenningsálitinu. Pví er mikilvægt að sem flestir almennir borgarar um allan heim láti málið til sín taka, eftir getu og aðstæðum. Mikið er í húfi, par sem önnur einræðisstjórnvöld, til dæmis í Venesúela, bíða nú og fylgjast grannt með hvort Tyrkir komist upp með að beita varðhaldi og sýndarréttarhöldum til að pagga niður í peim sem berjast fyrir bættum mannréttindum par í landi. 